\title{
A Business Model Approach for Service Engineering in the Internet of Services
}

\author{
Holger Kett \\ Competence Center Electronic Business \\ Fraunhofer-Institut für Arbeitswirtschaft und Organisation IAO \\ Nobelstr. 12 \\ 70569 Stuttgart \\ Holger.Kett@iao.fraunhofer.de
}

\begin{abstract}
In all major industrialized countries, the service sector is the largest economic segment maintaining the highest growth rate. A current trend in the Internet of Services is to develop and offer software as a service (SaaS). Some research activities, such as Theseus/TEXO ${ }^{1}$, focus on the design and development of Web-based service ecosystems based on Web-platforms which allow offering, trading, and executing of services over the Internet.

This paper is based on the Integrated Service Engineering (ISE) methodology, an interdisciplinary methodology for service engineering. The focus of this work is laid on the development of business models from a strategic-/marketoriented perspective, prior to consider the service business processes and the underlying IT-oriented service concept. The role of the business strategist and its objectives is introduced. The methodology has been developed in the Theseus/TEXO project which is funded by the German Federal Ministry of Economy and Technology ${ }^{2}$.
\end{abstract}

\section{Introduction}

Software development as an engineering discipline relies on formal models and methodologies. Models serve as development artefacts which can be explicitly measured, validated and adapted. Methodologies, on the other hand, control the software development process [WE02]. Since software is increasingly offered as a service [WRK10, LO07], the Theseus/TEXO project conducts research in the context of a Web-based platform which offers, trades, and executes software as a service (see [JRS08, BD06]).

\footnotetext{
${ }^{1} \mathrm{http} / / /$ theseus-programm.de/en-us/theseus-application-scenarios/texo/default.aspx

2 The project was funded by means of the German Federal Ministry of Economy and Technology under the promotional reference "01MQ07012". The authors take the responsibility for the contents.
} 
Prior to design the service processes and the service concept, a service provider or a consortium of service providers needs to agree on the services which are offered over the Internet. Those aspects are designed within a service concept (see [BFM03]) or a business model (see [OS04]) and further refined by a business process model and an IT-oriented service concept. The Integrated Service Engineering ISE methodology has been developed to support the engineering process of services in the context of the Internet of Services [KE09, KE08a].

\section{Methodology}

The basis of this work is the ISE methodology and its strategic perspective on a developing electronic business service. Relevant approaches for designing business models have been examined in the state-of-the-art by comparing the requirements from the viewpoint of organisations which collaborate to offer a service over the Internet. The major targets of applying business models in this context is to identify the crucial elements, describe and discuss them, assess the business model's feasibility, and finally, use and detail it in the further steps of ISE. None of the identified approaches sufficiently meet the targets. Therefore, a new approach for creating business models has been developed and evaluated.

\section{State-of-the-Art}

In this section, the following three approaches which focus on business models have been identified and examined. The terms service concept and business models are used as similar expressions within this work.

\section{Service concept [BFM03]}

The service concept is part of the service engineering process. Bullinger et al. [BFM03] introduce a structured approach for developing service similar to the technical discipline of product engineering. In this approach, three different models are subsumed in the service concept: Resource model, product model, and process model. Here, the participation of different partners in the service delivery process is not considered within the model as well as attributes which specify the model elements in more details. Also financial aspects are neglected.

\section{e3-Value Ontology [GA03]}

In comparison to the above-mentioned service concept, the $e^{3}$-value ontology strongly considers partner networks who offer a service. Therefore, the ontology differentiates between a value web perspective and a trust perspective. The value web perspective models the creation, distribution, and consumption of goods or services of economic value in a network of multiple enterprises and end-consumers. The goal of the methodology is to create a shared understanding of a business model for all actors involved, and to assess the potential profitability. However, the trust 
perspective describes how value webs can be expanded with trustworthy control procedures thus enhancing confidence of actors in each other to enable trading.

\section{Business Model Ontology [OS04]}

Osterwalder suggests a generic meta-model for the business models development. He analyses 14 different business model approaches in-depth and derives the generic meta-model from the results.

For the generic meta-model, Osterwalder has chosen elements which are interior to the business model, service, customer interface, infrastructure management, and financial aspects and, thus, can be directly influenced by an organization.

\begin{tabular}{|c|c|c|c|c|}
\hline Aspect & Explanation & $\sum_{i=1}$ & 8 & $\infty$ \\
\hline $\begin{array}{l}\text { Target } \\
\text { Customer }\end{array}$ & $\begin{array}{l}\text { Specification of the target customers and } \\
\text { their characteristics. }\end{array}$ & $\bullet$ & 0 & $\bullet$ \\
\hline $\begin{array}{l}\text { Service } \\
\text { Description }\end{array}$ & $\begin{array}{l}\text { Definition of the main features of a } \\
\text { developing service. }\end{array}$ & $\bullet$ & $\bullet$ & $\bullet$ \\
\hline $\begin{array}{l}\text { Service } \\
\text { Provisioning }\end{array}$ & $\begin{array}{l}\text { Specification of the main elements of the } \\
\text { service delivery process, i.e. key processes, } \\
\text { competencies, and resources. }\end{array}$ & $\bullet$ & • & $\bullet$ \\
\hline Profitability & $\begin{array}{l}\text { Estimation of the main costs and revenues to } \\
\text { calculate the profit for each partner. }\end{array}$ & 0 & $\bullet \bullet$ & $\bullet$ \\
\hline $\begin{array}{l}\text { Partner } \\
\text { Integration }\end{array}$ & $\begin{array}{l}\text { Address aspects of integration of partners } \\
\text { who provide competencies and resources for } \\
\text { the service delivery process. }\end{array}$ & 0 & $\bullet \bullet$ & $\bullet$ \\
\hline
\end{tabular}

Table 1: Comparison of business model approaches

The above-mentioned approaches have been examined towards the degree of meeting the above-mentioned major targets and compared on the following five aspects (see Table 1). The only approach which addresses all five aspects is the one from Osterwalder. However, the business model approach of Osterwalder does not meet the major targets since it does not provide the appropriate structure of describing the business model elements (complex structure and irrelevant elements/attributes for the service engineering context) and does not assess the business model's feasibility. Nevertheless, the business model approach of Osterwalder provides a suitable basis for an improved approach which is integrated in ISE. 


\section{Business Strategist and the Strategic Perspective}

Prior to introduce an approach for business model development, the key user needs to be assigned. Whereas, the roles of the functional-technical view, such as business analyst, service architect, and a service developer, are considered in service engineering research and methods [KE09, BO05, ZKG04], the roles of the strategic business-oriented view, such as a business strategist, are neglected. Figure 1 illustrates the relevant roles and the key position of the business strategist who acts between the market and the target customers, the partners, and the colleagues of the own organisation. The business strategist works with key service stakeholders to develop a strategic service concept which is also called business model [KE09]. The business model is passed to the following roles (see Figure 1) which further concretize the information in the subsequent steps of the service development process by designing complementary models [KE08a].

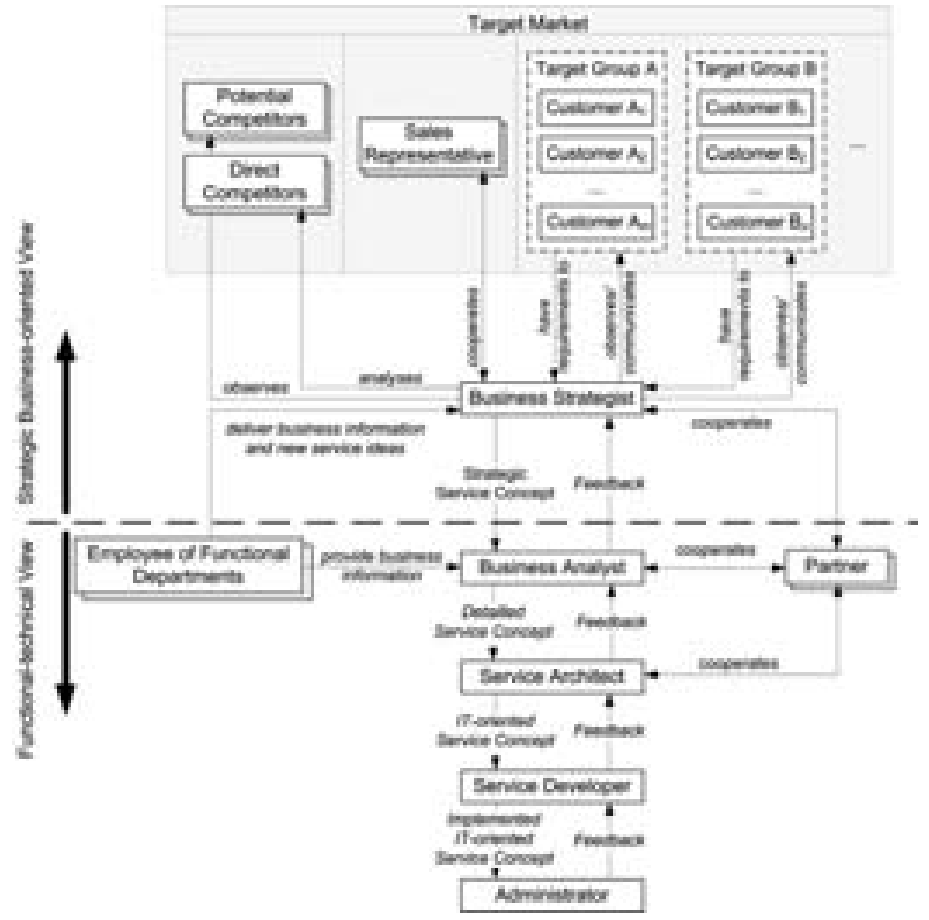

Figure 1: Roles and artefacts in the service engineering process

The different elements of a business model have been derived from already existing approaches as introduced above and their adaptations and improvements with organisations which develop Web-based services, such as IT-providers. Figure 2 shows the adapted business model approach which has been applied for the strategic 
design of a Web-based platform to support the sales processes of sales representatives and their manufacturers [KKW09], [KE08b]. The attributes, which have been assigned to each of the business model elements, have been to some extent specific to the mentioned scenario. The attributes are not listed within this work.

The following steps have been conducted for designing a business model:

1. Specification of the target customers: The target customers need to be identified and relevant attributes need to be described.

2. Description of the service: On the basis of the specified target customers the value proposition as well as the service is described. Here, the service itself but also the sales channels and the customer relationship needs to be specified.

3. Design of the service delivery: When the target customers as well as the service are specified, the service delivery process including the required competencies, resources and partners need to be fixed.

4. Estimation of profitability: In order to have a coarse-grained estimation of the profitability of the business model for each partner, the costs and the revenues are estimated and the profitability is calculated.

After running through the listed steps and specifying the elements and their attributes, the business model is defined. This result is passed to the next role (business analyst) of the ISE methodology which further refines the business model by focussing on the design of a business process model.

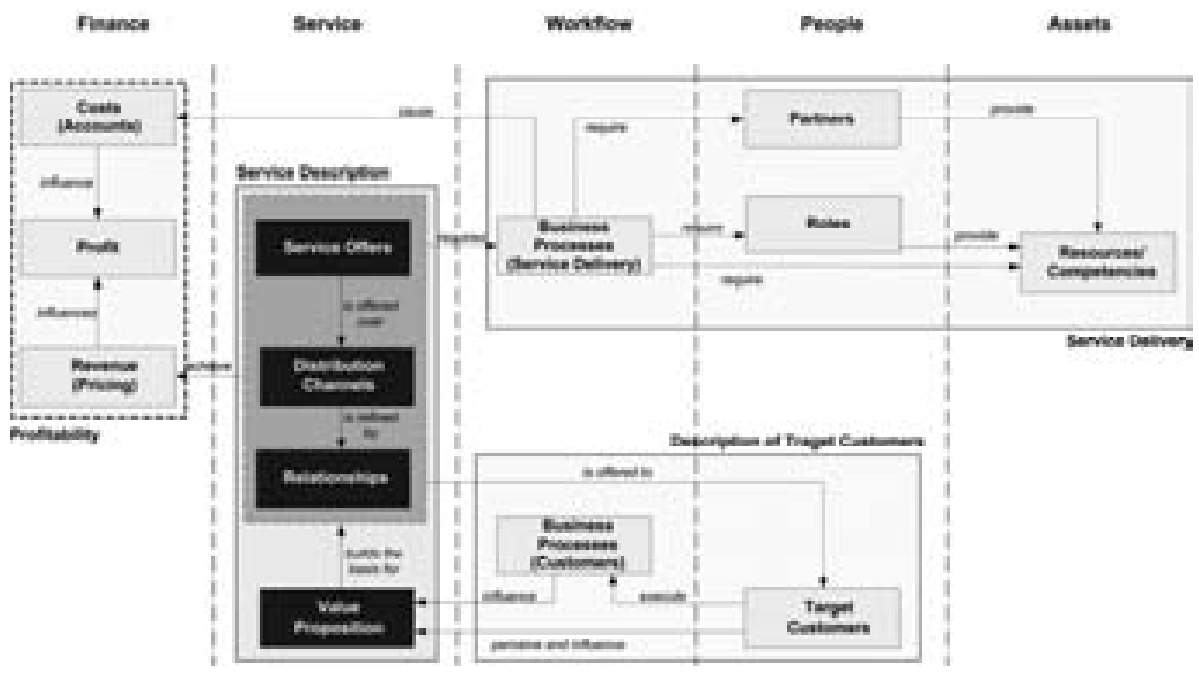

Figure 2: Business model within the ISE methodology

\section{Conclusion and Further Activities}

The development of a business model, prior to design the business process model (business analyst) and the IT-oriented service concept (service architect), is vital for a consortium of IT-providers who wants to collaborate to offer a service over the 
Internet. The introduced business model approach has been tested within a consortium of four IT-providers to strategically design a Web-based platform to support the sales processes of sales representatives and their manufacturers.

When applying this business model approach to services tradable and executed over the Internet, a service description language, such as USDL [CWV09], needs to be integrated. In this case, the business model can provide necessary information about services, such as price models and description of functionalities, and can be used in the context of dynamic service compositions.

\section{Bibliography}

[BD06] Barros, A. P.; Dumas, M.: The Rise of Web Service Ecosystems. In IT Pro, 2006, September/Oktober; pp. 19-25.

[BFM03] Bullinger, H.-J.; Fähnrich, K.-P.; Meiren, T.: Service engineering methodical development of new service products. In International Journal of Production Economics, 2003, 85; pp. 275-287.

[BO05] Bose, S. et al.: SOA Project Planning Aspects. IBMPress, 2005.

[CWV09] Cardoso, J.; Winkler, M.; Voigt, K.: A service description language for the internet of services. In Proceedings of ISSS, 2009.

[GA03] Gordijn, J.; Akkermans, H.: Value Based Requirements Engineering: Exploring Innovative e-Commerce Ideas.

[JRS08] Janiesch, C.; Ruggaber, R.; Sure, Y.: Eine Infrastruktur für das Internet der Dienste. In (Hofmann, J.; Meier, A. Eds.): Webbasierte Geschäftsmodelle. dpunkt, Heidelberg, 2008; pp. 71-79.

[KE08a] Kett, H. et al.: Service Engineering in Business Ecosystems. In (Ganz, W.; Kicherer, F.; Schletz, A. Eds.): New horizons for the role and production of services. RESER 2008. Conference proceedings. Fraunhofer IRB, Stuttgart, 2008a; pp. 0-22.

[KE08b] Kett, H. et al.: A mobile multi-supplier sales information system for microsized commercial agencies. In (Paul Cunningham Ed.): Collaboration and the Knowledge Economy: Issues, Applications, Case Studies. Pt.2 eChallenges e2008 Conference. IOS Press, Amsterdam, 2008b; pp. 1240-1247.

[KE09] Kett, H. et al.: Integrated Service Engineering (ISE) for Service Ecosystems: An Interdisciplinary Methodology for the Internet of Servcies. In: eChallenges e-2009 Conference Proceedings. IIMC International Information Management Corporation, 2009.

[KKW09] Kett, H.; Kokemüller, J.; Weisbecker, A.: Erweiterung von ERP-Systemen zur Anbindung von Handelsvertretungen. In ERP-Management, 2009, 5; pp. 26-28.

[LO07] Lorenz, O. et al.: eBusiness-Barometer 2007/2008. In (Lorenz, O.

Ed.): eBusiness 2007/2008. Jahrbuch der deutschen Wirtschaft. Wegweiser, Berlin, 2007; pp. 8-61.

[OS04] Osterwalder, A.: The Business Model Ontology. A Proposition in a Design Science Approach, Lausanne, 2004.

[WE02] Weisbecker, A.: Software-Management für komponentenbasierte SoftwareEntwicklung. Jost Jetter, Heimsheim, 2002.

[WRK10] Weiner, N.; Renner, T.; Kett, H.: Geschäftsmodelle im Internet der Dienste. Trends und Entwicklungen auf dem deutschen IT-Markt. Fraunhofer IRB, Stuttgart, 2010.

[ZKG04] Zimmermann, O.; Krogdahl, P.; Gee, C.: Elements of Service-Oriented Analysis and Design - An interdisciplinary modeling approach for SOA projects, 2004. 